\title{
Hunting large primates and conservation of the Neotropical rain forests
}

\author{
E. F. Ráez-Luna
}

This paper examines the impact of hunting on the conservation of large Neotropical primates ( $\geq 6 \mathrm{~kg}$ adult body mass) and of the forest they inhabit. A greater emphasis on the in-situ conservation of large cebids outside protected areas and close to people is advocated and research priorities are suggested to support the conservation of large primates imperilled by hunting.

Hunting has occurred for about 12,000 years throughout the Neotropical rain forests, and is currently a significant economic activity for the rural inhabitants of tropical America (Clay, 1988). For many local hunters, primates are an important prey. Vickers (1984) found that primates were hunted by 10 groups in eight Indian and five Mestizo (Spanish/ American Indian) societies of lowland South America, and were second in importance in the overall mammalian kills. Redford and Robinson (1987) took a larger sample of 16 Indian and six colonist communities. They found that, for Indians, primates were the most frequently hunted mammalian order, and the third one for colonists.

Not all primate species are equally ranked in the harvest data: the largest cebid monkeys ( $\geq 6 \mathrm{~kg}$ adult body mass), which yield the highest meat returns, are killed with particular enthusiasm. All the larger cebids - six species of Alouttinae monkeys (genus Alouatta) and seven species of Atelinae monkeys (genera Lagothrix, Ateles and Brachytheles) are actively hunted for meat throughout their ranges (Mittermeier, 1987; Emmons, 1990). The two genera hunted most frequently are the woolly monkeys (Lagothrix spp.) and the spider monkeys (Ateles sp.)

Extensive evidence indicates that populations of large cebids are seriously threatened throughout their ranges because of hunting (Mittermeier, 1987; Mittermeier and Cheney, 1987; Peres, 1991). Hunting has been repeatedly identified as an important factor influenc- ing patterns of large primate abundance in the Neotropics, as suggested from a number of comparisons between hunted and unhunted sites (Freese et al., 1982; Emmons, 1984; Mitchell and Ráez-Luna, 1990; Peres, 1990). Because hunting is performed without noticeable short-term floristic change, the ecological impact of hunting has only recently started to receive attention (for example, Redford and Robinson, 1985; Terborgh et al., 1986). Ecological extinction, 'the reduction of a species to such low abundance that, although it is still present in the community, it no longer interacts significantly with other species' (Estes et al., 1989), might be occurring in many game populations, particularly large cebids (Redford, 1992). Therefore, significant efforts for the conservation of large Neotropical primates must address hunting as a central factor.

Why should so much attention be paid to large primates? Limited but compelling data exist on the significance of seed dispersal by large non-volant mammals for rain forest regeneration (see Gentry, 1983). More specifically, direct and circumstantial evidence (van Roosmalen, 1985; Symington, 1988; Defler, 1989) indicate that large cebids, particularly the highly mobile spider and woolly monkeys, are one of the most important groups of mammalian seed dispersers (Terborgh, 1983; Bourlière, 1985; Redford, 1992).

Out of the $7-13$ primate species usually present in an Amazonian non-degraded forest, only one to three are large-bodied ( $n=24$ 
sites, data from Mittermeier and van Roosmalen, 1981; Freese et al., 1982; Peres, 1990). However, these few species can contribute about one-third to the non-volant mammalian biomass of the forest (Janson and Emmons, 1990), and as much as 49 per cent of its frugivore biomass (Terborgh, 1987). Thus, concentrating management efforts on one to three large monkey species (a tiny fraction of the vertebrate diversity of the forest) could influence positively both the trophic balance and the regeneration of the forest, along with its ability to support other primary consumers and their related species. Concomitantly, any severe reduction in the densities of large primates threatens the key ecological services they provide.

Thus, it is important to conserve healthy populations of large primates. However, while it is possible to protect populations within uninhabited parks and reserves, what will happen to the bulk of the primates, living in areas inhabited by humans and subject to hunting and habitat degradation? Most current initiatives of unsustainable development in the Neotropical rain forest propose improved logging and silvicultural practices or extraction of non-timber products (Anderson, 1990). These initiatives (genuine responses to the alarming rates of Neotropical deforestation) are almost exclusively aimed at protecting the tree cover, and can fail miserably in protecting vulnerable wildlife. At best we risk ending up with an empty and doomed greenery (see Redford, 1992).

Even in the few well-protected large parks, the effective size of primate populations can be limited by variability in habitat-specific carrying capacity, and by geographical limits to gene flow. A recognized characteristic of large cebid species is the high variability in abundances throughout their distributions (Robinson and Redford, 1987; Redford and Robinson, 1989; Arita et al., 1990). Part of this variability is caused by ecological factors, which make extensive parts of the rain forest unsuitable or suboptimal habitat for some large primate species. Geographical barriers, such as wide rivers and high mountains, also limit the size of populations and genetic flow between them*. A third barrier exists because of human activities. For example, the Andes of Ecuador and Colombia, which divide the Amazon from the Pacific rain forest, once held a number of patches of primate habitat but those old forest corridors have been extensively destroyed by deforestation.

While extensive rain forest still exists in parts of Amazonia, particularly in southern Colombia and south-east Peru, little remains in most other forested regions of tropical America, such as the Central American rain forests, the Chocó biogeographical region of Colombia and Ecuador, the Atlantic rain forest of Brazil, or the gallery forests of the savannah and cerrado. Most of the remaining forests are privately owned. A critical characteristic of the lowlands of tropical America is that they are largely inhabited by and under the political control of native peoples, who hunt, fish, cultivate plants and make a living out of those lands. In Brazil, Indian territories cover 791,354 sq km (Márez, 1992). In Peru, 1000 Indian communities occupy $736,443 \mathrm{sq} \mathrm{km}$ of Amazonian land (Beteta, 1992). In Colombia, 41 per cent of the country's rain forests are recognized Indian territories (about 200,000 sq km) (Colombia, 1990; Arango, 1992) and the new Colombian Constitution also recognizes the right of the Afroamerican inhabitants of the highly biodiverse Chocó region to own the rain forests communally (Colombia, 1993). By comparison, both in Colombia and Peru, the rain forest area protected within parks and reserves is less than $70,000 \mathrm{sq} \mathrm{km}$. These protected areas often overlap (sometimes completely) with the territories of native peoples.

Thus, sound conservation policies for the large South American monkeys must emphasize the management of lands inhabited by humans and not focus exclusively on the very few uninhabited regions. Management in inhabited areas should be performed with the goal of maximizing the overall viability of the rain forests, and their ability to support fully functional sets of Neotropical biodiversity,

* Ayres and Clutton-Brock (1992) discuss the role of Amazonian rivers as barriers to species-level dispersal of primates. A similar exercise at the population level has not yet been published. 
while still providing resources for local peoples. Also, management of areas inhabited by humans should take into account the already deep and growing involvement with the market economy that characterizes most rural communities of tropical America, be they native or not. Such initiatives are just starting; I discuss two of these below.

\section{Hunting and conservation of large cebids}

First, the Tamshiyacu-Tahuayo Communal Reserve, in north-east Peru, a 3225-sq-km area inhabited by ribereños (non-tribal people). These people recognized the degradation occurring in the forest they inhabit as a result of uncontrolled exploitation of timber, game animals, palm fruits and fish. They wanted to limit access to their territory and reduce the damage to the forest. They approached local officials and scientists working in the area in search of legal and technical support. The new rules needed to harmonize the involvement of the ribereños with the local markets and the biological constraints to the exploitation of forest products. As a result, a set of access and management rules are being developed, including the declaration of a communal reserve, a ban on the hunting of primates and tapir, and the controlled hunting and commercialization of deer, peccaries and game rodents (Bodmer, 1993 and pers. comm; L. Moya, ms [undated]).

A second project is under way in the Utría National Natural Park in the Colombian Chocó, by means of a multi-institutional collaboration involving an Indian organization (OREWA), the government office for natural resources (INDERENA) and a conservation non-governmental organization (Fundación Natura). Up to 85 per cent of the park overlaps with Embera Indian territories. There, after 2 years of monitoring subsistence hunting with direct participation from the Embera Indians, strategies of sound wildlife management are being discussed in workshops that involve scientists, ethnic leaders and whole communities. Proposed plans include the delimitation of wildlife refuges within the Indian territories, which would be policed by the Embera themselves, and the revival of traditional management rules such as prolonged close seasons on endangered game, which in the past were declared by the jaibaná (Embera shamans) (Rubio-Torgler, 1992; H. Rubio-Torgler, pers. comm.). As these and other initiatives develop, a more detailed knowledge of the factors limiting the survival of hunted populations of Neotropical wildlife will be increasingly needed. For large cebids, a set of basic questions could be:

1 What are the ecological determinants of the high variability in abundance displayed by large cebid monkeys? The little we know suggests that, besides hunting, at least two other factors interact to influence the largecebid-species composition of a forest: (a) habitat variations in terms of food supply, vegetation structure and natural disturbance; and (b) interspecific competition (Robinson and Redford, 1987). The features of this three-factor interaction are still to be determined.

2 What is the effect of intergroup dispersal on the ability of populations of large cebids to survive hunting? In predator-prey theory, dispersal of prey from predator-free patches (sources) into predated areas (sinks) is considered a key factor in prey persistence (for example, Roff, 1974; Hillborn, 1979). However, exploratory calculations suggest that the rates of successful dispersal among slow-maturing and slow-reproducing large cebids could be too small to have any significant influence on the persistence of hunted populations (RáezLuna, 1993). More field data are needed to determine whether this is true.

3 What are the minimum values of demographic parameters for viable populations of large cebids? Kinnaird and O'Brien (1991) applied two different approaches to the estimation of minimum viable sizes for populations of Kenyan crested mangabey monkeys Cercocebus galeritus galeritus and found that the resulting numbers were impossible to achieve in the field. No similar exercise for large Neotropical primates is known. However, simulation models of populations of large cebids suggest that, when adult female survival 
rates fall below around 75 per cent, populations tend to collapse (Dobson and Lyles, 1989; Ráez-Luna, 1993). The message of these studies about the vulnerability of large monkeys is clear, but it cannot replace the value of obtaining accurate numbers for management purposes.

4 What are the effects of hunting on the population dynamics of large cebids? What criteria should we use in the monitoring of hunted large monkeys? Both field evidence (Peres, 1990) and simulation models (Ráez-Luna, 1993) predict that shotgun-hunted populations of large cebids inevitably go extinct within 20-30-years, due to the efficiency of shotguns in killing arboreal prey (Hames, 1979; Alvard and Kaplan, 1991). Simulations also suggest that ecological extinction (defined as longterm abundances at least one order of magnitude below carrying capacity) can occur in populations of spider and woolly monkeys even if hunted with low-efficiency traditional weapons, such as bows and arrows. Hunting can also create great imbalance in the age structure of the populations, which finally leads to massive local extinctions (Ráez-Luna, 1993). We need to evaluate these predictions in the field because they could supply useful criteria for the monitoring of hunted populations of large cebids.

5 What is the real significance of large cebids as seed dispersers? What would be the longterm effects of the decline of populations of large cebids on forest dynamics? What levels of large cebid abundance should be considered ecological extinction? As stated above, there is only limited and circumstantial evidence to support the hypothesis that large cebids are key seed dispersers. What is not in doubt is their great contribution to the primary consumer biomass of the Neotropical rain forests. Even if it proved that they play only a minor role in seed dispersal, the loss of frugivore biomass contributed by large primates could have deep and deleterious effects on the forest.

While we still largely ignore what the processes could be, and what levels of killing of large cebids can trigger them, hunting will continue to occur in the Latin American rain forests ... as long as they last.

\section{Acknowledgments}

My research on Neotropical hunting was supported by the Wildlife Conservation Society (founded in 1895 as the New York Zoological Society), the Jessie Smith Noyes Foundation, the Peruvian Association for the Conservation of the Southern Rainforest, and the Tropical Conservation and Development Program at the University of Florida. Richard Bodmer and Heidi Rubio-Torgler provided helpful information and comments on this paper. Kent Redford provided sustained encouragement.

\section{References}

Anderson, A.B. (ed.) 1990. Alternatives to Deforestation: Steps Towards Sustainable Use of the Amazon Rain Forest. Columbia University Press, New York.

Alvard, M.S. and Kaplan, H. 1991. Procurement technology and prey mortality among indigenous Neotropical hunters. In Human Predators and Prey Mortality (ed. M. C. Stiner), pp. 79-104. Westview Press, Boulder.

Arango, R. 1992. Situación territorial y tratamiento legal de las áreas indígenas del litoral pacífico y de la Amazonia de Colombia. In Derechos Territoriales Indigenas y Ecologia en las Selvas Tropicales de América (eds Fundación GAIA and CEREC), pp. 223-259. GAIA/CEREC, Bogotá.

Arita, H.T., Robinson, J.G. and Redford, K.H. 1990. Rarity in Neotropical forest mammals and its ecological correlates. Conservation Biology, 4 (2), 181-192.

Ayres, XX and Clutton-Brock, T.H. 1992. River boundaries and species range size in Amazonian primates. The American Naturalist, 140 (3), 531-537.

Beteta, C. 1992. Condición jurídica de la tenencia de la tierra en zonas de selva y ceja de selva peruanas, por comunidades nativas, y régimen legal de manejo de los recursos naturales. In Derechos Territoriales Indigenas y Ecología en las Selvas Tropicales de América (eds Fundación GAIA and CEREC), pp. 139-156. GAIA/CERECBogotá.

Bodmer, R.E. 1993. Managing wildlife with local communities: the case of the Reserva Comunal Tamshiyacu-Tahuayo. Prepared for the Liz Claiborne Art Ortenberg Foundation Community Based Conservation Workshop. Airlie, Virginia.

Bourlière, F. 1985. Primate communities: their structure and role in tropical ecosystems. International Journal Primatology, 6 (1), 1-26.

Clay, J.W. 1988. Indigenous Peoples and Tropical Forest: Models of Land Use and Management from Latin America. Cultural Survival Inc. Cambridge, 
Massachusetts.

Colombia, República de, 1990. Política del Gobierno Nacional para la Defensa de los Derechos Indígenas y la Conservación Ecológica de la Cuenca Amazónica. Santafé de Bogotá.

Colombia, República de. 1993. Ley de Comunidades Negras (Ley 70). Santafé de Bogotá.

Defler, T.R. 1989. Recorrido y uso del espacio en un grupo de Lagothrix lagothricha (Primates: Cebidae) mono lanudo churuco en la Amazonia colombiana. Trianea, 3, 183-205.

Dobson, A.P. and Lyles, A.M. 1989. The population dynamics and conservation of primate populations. Conservation Biology, 3 (4), 362-380.

Emmons, L.H. 1984. Geographic variation in densities and diversities of non-flying mammals in Amazonia. Biotropica, 16 (3), 210-222.

Emmons, L.H. 1990. Neotropical Rainforest Mammals, A Field Guide. University of Chicago Press, Chicago.

Estes, J.A., Duggins, D.O. and Rathbun, G.B. 1989. The ecology of extinctions in kelp forest communities. Conservation Biology, 3 (3), 252-260.

Freese, C.G., Heltne, P.G., Castro, N. and Whitesides, C. 1982. Patterns and determinants of monkey densities in Peru and Bolivia, with notes on distributions. International Journal Primatology, $3(1), 53-90$.

Gentry, A.H. 1983. Dispersal ecology and diversity in Neotropical forest communities. Sonderb. Naturwiss. Ver. Hamgbg. 7, 303-314.

Hames, R. B. 1979. A comparison of the efficiencies of the shotgun and the bow in Neotropical forest hunting. Human Ecology, 7 (3), 219-252.

Hillborn, R. 1979. Some long-term dynamics of predator-prey models with diffusion. Ecological Modelling, 6, 23-30.

Janson, C.H. and Emmons, L.H. 1990. Ecological structure of the non-flying mammal community at Cocha Cashu Biological Station, Manu National Park, Peru. In Four Neotropical Rain Forests (ed. A. H. Gentry), pp. 314-338. Yale University Press, New Haven, Connecticut.

Kinnaird, M.K. and $\mathrm{O}^{\prime}$ Brien, T.G. 1991. Viable populations for an endangered forest primate, the Tana river crested mangebey (Cercocebus galeritis galeritus). Conservation Biology, 5 (2), 203-212.

Márez, C. 1992. Brasil, Amazonia e indios: el derecho en jaque. In Derechos Territoriales Indígenas y Ecología en las Selvas Tropicales de América (eds Fundación GAIA and CEREC), pp. 75-90. GAIA/CEREC, Bogotá.

Mitchell, C.L. and Ráez-Luna, E.F. 1990. Los efectos de la caza por natívos en la densidad de presas en el Parque Nacional del Manu, Perú. Paper presented at the International Meeting on Experiences for the Sustainable Development of
Amazonia. APODESA-RONCO and US-AID, organizers. Lima, Perú.

Mittermeier, R.A. 1987. Effects of hunting on rainforest primates. In Primate Conservation in the Tropical Rainforest (eds C. Marsh and R. A. Mittermeier), pp. 109-146. Alan R. Liss Inc., New York.

Mittermeier, R.A. and Cheney, D.L. 1987. Conservation of primates and their habitats. In Primate Societies (eds B. B. Smuts, D. L. Cheney, R. M. Seyfarth, R. W. Wrangham and T. T. Struhsaker), pp. 477-490. University of Chicago Press, Chicago.

Mittermeier, R.A. and van Roosmalen, M.G.M. 1981. Preliminary observations of habitat utilization and diet in eight Surinam monkeys. Folia Primatologica, 36, 1-39.

Moya, L. (undated). Propuesta para la creación de la Reserva Comunal Tamshiyacu-Tahuayo, Loreto, Perú. Ministerio de Agricultura, Unidad Agraria XXII, Loreto, Perú, ms.

Peres, C.A. 1990. Effects of hunting on Western Amazonian primate communities. Biological Conservation, 54, 47-59.

Peres, C.A. 1991. Humboldt's woolly monkeys decimated by hunting in Amazonia. Oryx, 25 (2), 89-95.

Ráez-Luna, E.F. 1993. Modelling hunted populations of Alouatta seniculus, Ateles paniscus and Lagothrix lagothricha (Primates: Cebidae): chances of persistence and lessons for conservation. MA thesis, University of Florida, Gainesville.

Redford, K.H. 1992. The empty forest. Bioscience, 42 (6), 412-422.

Redford, K.H. and Robinson, J.G. 1985. Hunting by indigenous peoples and conservation of game species. Cultural Survival Quarterly, 9 (1), 41-43.

Redford, K.H. and Robinson J.G. 1987. The game of choice: patterns of Indian and colonist hunting in the Neotropics. American Anthropologist, 89 (3), 650-667.

Redford, K.H. and Robinson J.G. 1989. Body size, diet, and population variation in Neotropical forest mammal species: predictors of local extinction? In Advances in Neotropical Mammalogy (eds K. H. Redford and J. F. Eisenberg) pp. 567-594. Sandhill Crane Press, Inc., Gainesville.

Robinson, J.G. and Redford, K.H. 1987. Determinants of local rarity in Neotropical primates. Paper presented at the III Brazilian Primatology Congress, Federal University of Juíz de Fora, Minas Gerais, 1-6 February 1987.

Roff, D.A. 1974. The analysis of a population model demonstrating the importance of dispersal on a heterogeneous environment. Oecologia, 15, 259-275.

Rubio-Torgler, H. 1992. Proceso para concertar el 
manejo de fauna por parte de las comunidades indígenas del Parque Nacional Natural Utría, Chocó, Colombia. Report to Fundación Natura, OREWA, INDERENA, FEN, and WCI(NYZS). Bogotá.

Symington, M.M. 1988. Demography, ranging patterns and activity budgets of black spider monkeys (Ateles paniscus chamek) in the Manu National Park, Peru. Amer. J. Primatol. 15, 45-67.

Terborgh, J.W. 1983. Five New World Primates: A Study in Comparative Ecology. Princeton University Press, Princeton.

Terborgh, J.W. 1987. Conserving New World primates: present problems and future solutions. In Primate Ecology and Conservation. Proc. 10th Intl
Primatol. Soc. Vol. 2. (eds. J. Else and P. C. Lee), pp. 355-366.

Terborgh, J.W., Emmons, L.H. and Freese, C. 1986. La fauna silvestre de la Amazonia: el despilfarro de un recurso renovable. Boletin de Lima, 46, 77-85.

van Roosmalen, M.G.M. 1985. Habitat preferences, diet, feeding strategy and social organization of the black spider monkey (Ateles paniscus paniscus Linnaeus 1758) in Suriname. Acta Amazonica, 15 (3/4), suppl.

Vickers, W.T. 1984. The faunal components of lowland South American hunting kills. Interciencia, 9 (6), 366-376.

Ernesto F. Ráez-Luna, AA 777000, Bogotá, Colombia. 